\title{
Doctors and the test ban: 25 years on
}

\author{
Andrew Haines, Martin Hartog
}

Twenty five years ago on 5 August 1963 the partial test ban treaty was signed, almost exactly 18 years after the bombing of Hiroshima. The treaty banned the testing of nuclear weapons "in the atmosphere; beyond its limits including outer space; or underwater ..." and followed several years of discussion and negotiations between the United States and the United Kingdom on the one hand and the Union of Soviet Socialist Republics on the other.

The atomic bombs dropped on Hiroshima and Nagasaki in 1945 were both fission devices with an approximate explosive power of, respectively, 13 and 22 thousand tons (kilotons) of trinitrotoluene (TNT). Subsequently fusion devices (the hydrogen bomb), which potentially have virtually unlimited power, were developed, the first being tested in 1951 . Thus the total amount of high explosive used throughout the whole of the second world war, which has been estimated to be about 3 million tons (megatons) of trinitrotoluene, can be delivered by a single nuclear weapon within a fraction of a second. After their initial development in the United States nuclear weapons were acquired first by the Union of Soviet Socialist Republics and then by the United Kingdom, France, and China. Several other countries probably have nuclear weapons or are "nuclear capable," including Israel, South Africa, and India. Up to the end of 1987 the number of nuclear test explosions has been estimated to be 1754 , including 46 in 1987.

London N195 HT

Andrew Haines, MD, professor

University Department of Medicine, Southmead Hospital, Bristol BS10 5NB

Martin Hartog, DM, reader

Correspondence to: Professor Haines.

\section{Concern over testing}

Nuclear weapons tests first became an object of major public concern in 1954, when on 1 March a hydrogen bomb codenamed BRAVO was detonated at Bikini Atoll in the Pacific. The yield was twice that predicted and was equivalent to around 15 megatons.
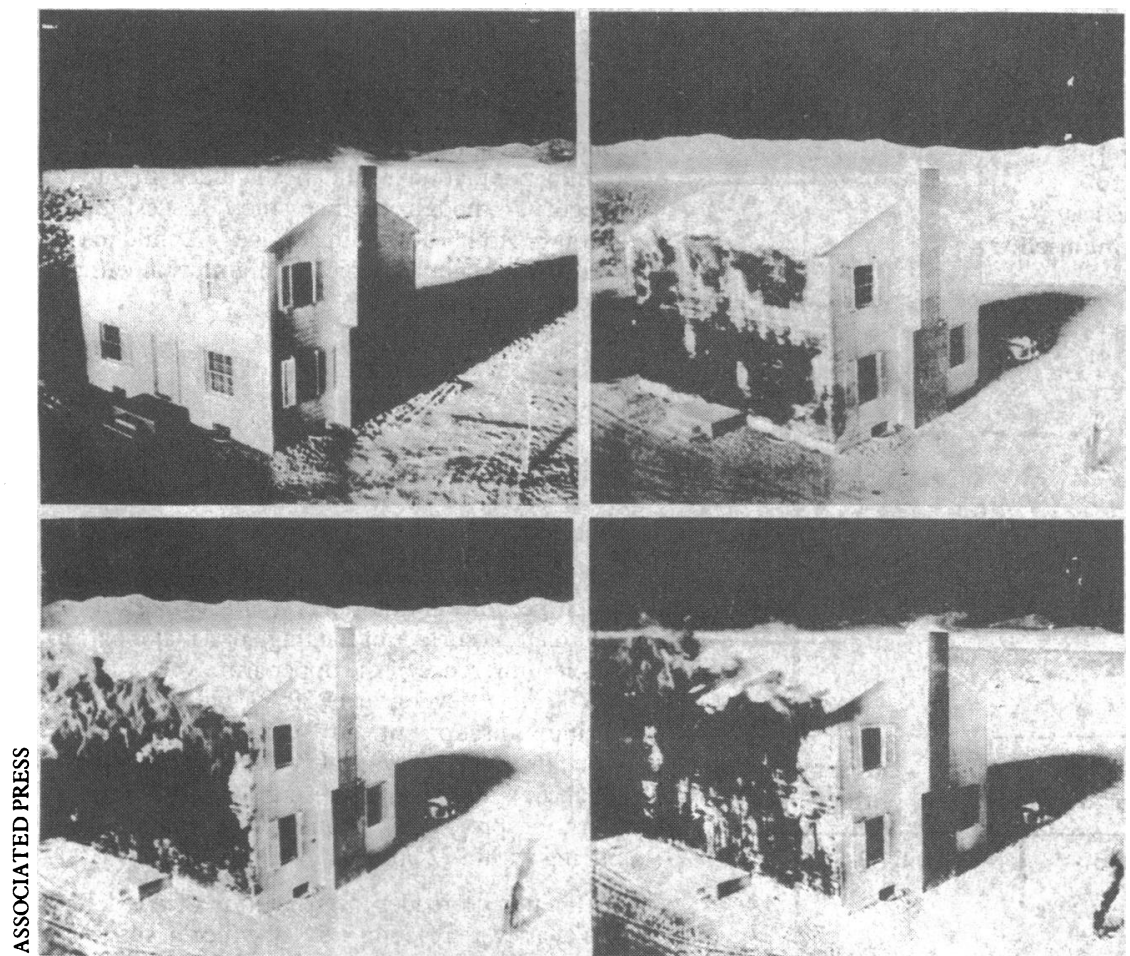

The front of this test house, 1050 metres from an atomic blast, was ablaze within one third of a second. This sequence of pictures shows the house lit by the glare of the flash (upper left). Remaining pictures al taken during the first second show the whole front ablaze. An instant later the blast wave snuffed out the flame.
The crew of a Japanese trawler experienced heavy radiation exposure and one of the 23 crew members died.' Inhabitants of the Marshall Islands were also exposed, although to a lesser extent, and subsequently suffered radiation effects, including an increased incidence of thyroid abnormalities and thyroid cancer, particularly in children. ${ }^{3}$ After the BRAVO test there was a storm of protest, including statements from many world leaders such as Prime Minister Nehru of India, Pope Pius XII, and Albert Einstein as well as the Federation of American Scientists. At the Geneva summit of 1955, however, the four major powers could not reach agreement.

\section{Schweitzer's appeal}

As atmospheric testing continued Albert Schweitzer broadcast an appeal in 1957 for a ban on nuclear tests which was heard in 50 countries, and Linus Pauling collected signatures from over 9000 scientists from 43 countries also urging a test ban. Having won the Nobel Prize in 1954 for his work on molecular structure, he was to be awarded the Nobel Peace Prize in 1963 for his opposition to nuclear testing. Other scientists such as Edward Teller (now a fervent supporter of "star wars") were strong advocates of continued testing. Rising anxiety among the public and scientists about the potential hazards of atmospheric testing led to the formation of a special subcommittee of the Joint Committee on Atomic Energy in the United States to consider the nature of radioactive fallout and its effects on humans.

Most of the concern about the effects of testing nuclear weapons in the atmosphere is because of the possible effects of long lived isotopes, particularly strontium-90, caesium-137, and carbon-14 with half lives of 28,30 , and 5730 years, respectively. There are three classes of fallout: local, tropospheric, and stratospheric. Tropospheric and stratospheric fallout can be widespread. Tropospheric fallout occurs from a few weeks to several months after an explosion; it tends to be carried around the world in the same general band as that in which it originated, and its deposition is determined by the precipitation of rain and snow. Stratospheric fallout may ultimately spread world wide.

In 1957 the British Atomic Scientists' Association appointed a committee to study the problem of radiation hazards from fallout. ${ }^{5}$ The committee, chaired by Professor Joseph Rotblat, expressed particular concern about the risk of inducing malignancies, especially leukaemia and bone cancer from strontium-90, which imparts most of its radioactivity to bone and bone marrow. It suggested that if the assumption of a proportional relation between exposure and the induction of cancer was correct roughly 1000 people might ultimately develop bone cancers for every megaton exploded in the atmosphere. The committee pointed out that these would represent only a small fraction of the prevailing number of bone cancers and would not be recognised individually as being induced by radiation. Calculations of the collective dose of radiation from tests carried out to the end of 1980 suggested that this was equivalent to about four extra years of exposure of the world population to natural background radiation. ${ }^{6}$ Exposure to carbon- 14 will continue for thousands of years to a no doubt larger world population.

A study of mortality and the incidence of cancer in 
around 22000 men who participated in the United Kingdom's atmospheric nuclear weapon tests and in a control group has recently shown an excess of deaths due to leukaemia (22 $v 6)$ and myeloma $(6 v 0)$ in the test veterans but no significant overall difference in mortality.

\section{Negotiations for a test ban treaty}

The ascendance of Nikita Kruschchev to the position of Soviet premier in 1958 was followed rapidly by an announcement that the Supreme Soviet had approved a statement prohibiting further nuclear testing by the Soviet Union, provided that other nations followed suit. In reply President Eisenhower proposed a conference of technical experts to discuss requirements for verification. The experts met at Geneva and rapidly agreed a system for detecting clandestine tests. After this the United Kingdom, United States, and Soviet Union agreed to start formal negotiations and stop testing.

There were, however, important weaknesses in the experts' proposals in that inadequate consideration was given to the possibility of concealing tests and the provisions for on site inspections were vague. Furthermore, the system of monitoring proposed was impractical, depending on about 170 land based posts and 10 specially equipped ships as well as flights to investigate suspicious events. These activities might have meant that several thousand scientists were stationed at many, often remote, locations for long periods. ${ }^{8}$ Furthermore, subsequent experiments on underground tests suggested that the ability of the seismic techniques available at the time to detect underground tests had been overestimated. The possibility of evading detection by detonating a bomb in a large underground cavity - "cavity decoupling"was also raised.

The Soviet Union strongly resisted proposals for increased numbers of inspections of possible test sites, although some progress was made on this and other issues dividing the two sides. The Geneva talks, however, collapsed in 1960 amid increasing tension between East and West over various issues. After President Kennedy's election in 1961 the negotiations were revived but showed little progress, and at the end of 1961 the Soviet Union resumed testing, having expressed its criticism of the continued French testing, which they accused the United States and the United Kingdom of having failed to restrain. The Soviet Union exploded 50 nuclear weapons in the atmosphere in 60 days; the United States detonated a small series of underground explosions in the remainder of 1961 and restarted atmospheric tests in 1962, conducting nearly 100 tests in that year.

\section{Medical and scientific concern grows}

In 1961 and 1962 a number of scientific and medical papers on nuclear testing and the medical implications of nuclear weapons were published, reflecting the growing interest and concern with the issue. ${ }^{9.13}$ A statement from the Medical Research Council pointed out that between 1958 and 1959 the ratio of strontium-90 to calcium in the average diet in the United Kingdom had increased by half but had fallen in 1960 as a consequence of the test moratorium. ${ }^{14}$ Assays of human bone during 1956-60 showed the highest concentrations of strontium-90 to be in tissue of children around 1 year old. It was estimated that after the recent (1961) Soviet test series the exposure to radiation from iodine-131 (a comparatively short lived isotope absorbed into the body) in infants in their first year of life was approaching that from background radiation. Dairy products were a main source of exposure to both iodine-131 and strontium-90. In the

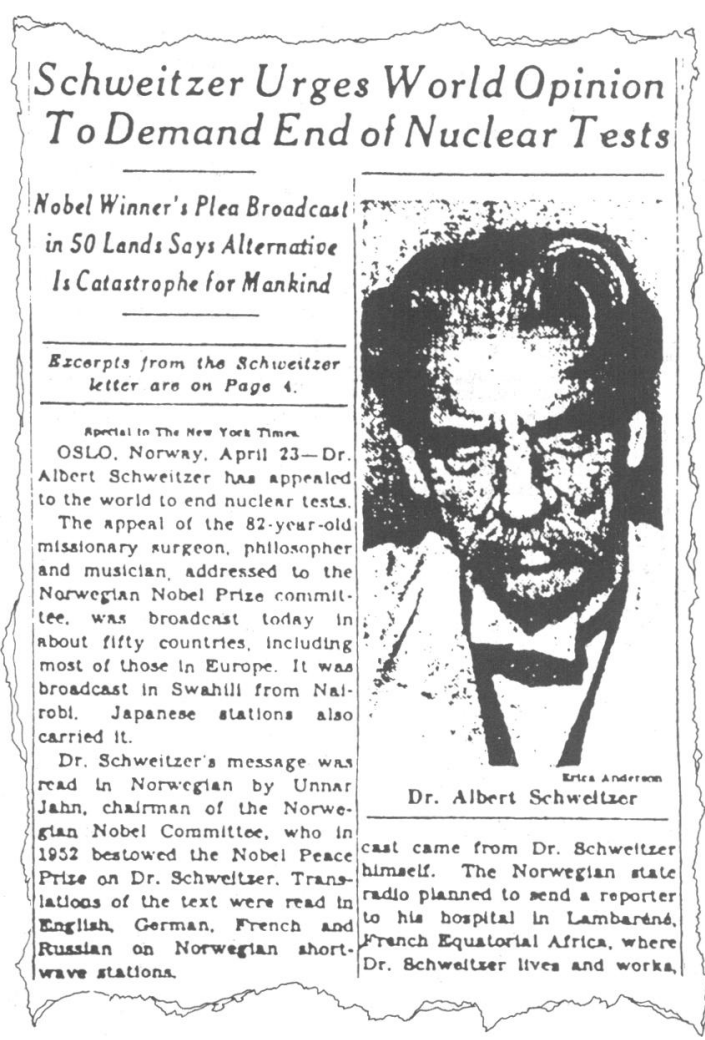

United States the St Louis Committee for Nuclear Information encouraged dentists to send in children's deciduous teeth to measure the concentrations of strontium-90 and subsequently publicised its findings. ${ }^{\text {14a }}$

Some commentators, however, thought that fallout was a small price to pay for keeping communism at bay. Writing in the fournal of the South Carolina Medical Association, Dr Thomas Parker noted that, "Communist Russia is at war with the United States in an all out war to the death. Their leaders have stated this so often that documentation seems unnecessary." He thought that the choice between "a potential danger as regards leukaemia of $0-60000$ cases per year if we continue testing atomic weapons indefinitely" and "the literal destruction of fifty to sixty million Americans in the possible future" should not be difficult "to a disciplined and educated mind."'s

Other medical viewpoints were more influential. Four articles in the New England Fournal of Medicine during 1962 described the effects on Massachusetts of a thermonuclear attack on the United States, the physician's role in the post attack period, radiation terminology, and the psychiatric and social aspects of civil defence. ${ }^{16-19}$ These articles had a large impact on medical and public opinion. Several thousand reprints were ordered by the Pentagon and they were summarised and reviewed in many papers including the New York Times, Newsweek, and Scientific American. The editor's note accompanying the four articles pointed out that the authors represented a new organisation, Physicians for Social Responsibility (PSR), which had been formed a few months before. The new organisation issued a statement of purpose, "PSR is an association of doctors concerned with the challenge of the nuclear age: man's scientific knowledge now provides an unprecedented opportunity for medical and social advance; yet modern warfare poses a supreme threat to the health and survival of mankind." They concluded that as no effective treatment was possible for victims of nuclear war doctors must "begin to explore a new area of preventive medicine, the prevention of thermonuclear, chemical and biological warfare."

Physicians for Social Responsibility continues to this 


\section{Dr.Spock radioactive fallout and your child:}

"We have been deeply concerned abol due to nuclear testing that as a result of the fallou from past tests, at least a small percentage of our children will develop cancer or leu. kemian in the future. and that some of ayr deformities or mental deficiency if testing in the atmosphere continues, the risks will increase. "After many unsuccess fut attempts in past years, American and Soviet negotiators have at last reached a test ban agreement. But it will rot become operative uniess
tatified by the United States Senate. their feeings to their Senators. We urge al Senators to support the Test Ban Treaty."

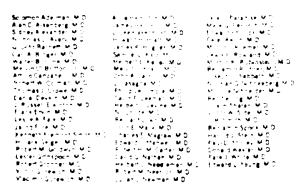

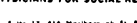

jamin Spock's

Dr Benjamin Spock's 政 Post 13 September 1963 day and is an organisation with about 30000 members; it has experienced a noticeable resurgence since 1980.

\section{The partial test ban treaty}

Further impetus to discussions on a test ban treaty was provided by the Cuban missile crisis of October 1962. Deadlock on the number of on site inspections and seismic monitoring stations prevented a comprehensive test ban from being achieved. A limited treaty banning atmospheric tests in particular, which had strong public support, seemed to be the only option in the circumstances. In the event the final negotiations were completed within 12 days in Moscow, with Lord Home signing for the United Kingdom. It has subsequently been signed by over 110 nations. Members of Physicians for Social Responsibility testified before the Senate Foreign Relations Committee and wrote to every senator urging ratification of the treaty. Advertisements signed by prominent doctors were placed in the Washington Post and other newspapers around the United States. Dr Benjamin Spock, the renowned paediatrician and a member of Physicians for Social Responsibility, wrote to thousands of doctors urging a special effort to ensure ratification. A Gallup poll in September 1963 indicated four to one support for the treaty among the public, and in a Harris survey the margin was 10 to one, concern about fallout being the most important factor accounting for this massive public support. . Similarly, and no doubt partly as a result of the activities of Physicians for Social Responsibility, fallout was also the single subject that drew the most questions from the senators at the ratification hearings.

Although the treaty largely solved the problem of radioactive contamination from fallout, it has failed to prevent continued development of nuclear weapons, for which a comprehensive treaty banning all nuclear tests is an essential prerequisite.

\section{Towards a comprehensive test ban treaty}

The worldwide stockpile of nuclear weapons currently has an explosive power of around 15000 megatons. The intermediate nuclear forces treaty, although a milestone in the history of nuclear arms negotiations, will only reduce the superpowers' nuclear arsenals by about $4 \%$. In the face of this massive overkill it is difficult to justify the further development of nuclear weapons. Nevertheless, testing continues and is primarily for the development of new nuclear weapons such as the nuclear pumped $x$ ray laser, which is a component of the strategic defense initiative (star wars) programme. Many believe that these new developments are destabilising and that they conflict with the commitment given by the United Kingdom, United States, and the Soviet Union as signatories of both the partial test ban treaty and the non-proliferation treaty to persist with negotiations for "the discontinuance of all test explosions of nuclear weapons for all time."

The two main arguments against a comprehensive test ban treaty, apart from the desire to develop new nuclear weapons, are the difficulty in detecting clandestine testing and the need to test the reliability of existing nuclear stockpiles. Great progress has, however, been made in the capacity to verify adherence to a comprehensive test ban treaty over recent years, partly because of advances in seismic detection of explosions and their discrimination from earthquakes. Thus, for example, a recent experiment conducted in the Soviet Union by an American and Soviet team of scientists showed that distinct seismic signals were recorded from underground blasts of conventional explosives with a yield of only 20 tons $(0.02$ kilotons $)$ at distances of up to $630 \mathrm{~km}$ from the test site and that these signals could be clearly discriminated from those of a small earthquake that occurred just before one of the tests. ${ }^{21}$ Furthermore, the Soviet Union has indicated that it is now prepared to accept stringent verification procedures. In addition, satellite surveillance makes the clandestine excavation of large cavities for secret testing difficult to conceal.

A recent study by a senior physicist at the Lawrence Livermore Laboratory in California concluded that the director of the laboratory had been incorrect when he told the United States congress that continued nuclear testing is required to ensure the reliability of the American nuclear arsenal.22 Other prominent people with detailed knowledge of designing nuclear weapons have also testified that continual testing is not necessary for ensuring the reliability of the stockpile. ${ }^{23}$

The moratorium on nuclear testing by the Soviet Union in 1985 did not evoke a similar response from the United Kingdom and the United States, and the Soviet Union has now resumed testing. Negotiations for a comprehensive test ban treaty were broken off by the United States in 1980, but talks are currently taking place on improved verification of the threshold test ban treaty of 1974 and the peaceful nuclear explosion treaty of 1976, which ban tests and "peaceful" explosions above 150 kilotons. These talks might lead to progress on a comprehensive ban. Alternatively, it might be possible to amend the partial test ban treaty to make it comprehensive. The first step towards this end has been taken with a resolution at the United Nations recommending that an amendment conference be called. Only three countries, the United States, the United Kingdom, and France, opposed the resolution, which was passed with 101 supporting votes.

\section{The medical role}

The World Health Organisation estimated that about $6 \%$ of the world's gross domestic product was spent on arms in 1985, of which nuclear weapons accounted for about $15 \%$, amounting to more than $\$ 166$ billion. ${ }^{2+}$ The United Kingdom spends about $5 \cdot 2 \%$ of its gross domestic product on defence, which is a higher proportion than nearly all other advanced Western nations, whereas its expenditure of around $6 \%$ on health is among the lowest. Not only are vast sums of money spent upon nuclear weapons but also about half of the total publicly funded research and development budget in the United Kingdom is devoted to the arms industries. This amounted to $£ 2.3$ billion in 1986 compared with $£ 127 \mathrm{~m}$ allocated by the government to the Medical Research Council. ${ }^{25}$

Enormous scientific skill is currently absorbed by the arms industries, including the nuclear weapons establishment, and there is great potential for the application of this skill to more socially useful activities. For example, alternative technology agencies have been set up, some of them by ex-members of the Lucas Aerospace workforce, who in 1976 formulated a corporate plan for the conversion of weapons technologies to peaceful uses. Among the products that have been developed in this way are the Monseco advanced dehumidifier to combat dampness in houses, a speaking computer spreadsheet for the blind, the BEA lift bath aid for handicapped children, and a ventilator alarm for patients with impairment of breathing from neurological disorders. ${ }^{26}$

In some of the poorest countries expenditure on armaments is many times that on health; thus the improvement of health in the Third World is inextricably linked with the need to reduce military expenditure. ${ }^{27}$

Several reports assessing the effects of nuclear weapons emphasise their destructive power and the 
appalling number of casualties that their use would produce. Prominent among these was the BMA's report of 1983, which concluded that the casualties arising from a single 1 megaton bomb would overwhelm the entire resources of the NHS..$^{28}$ This report has been followed by one on the likely environmental consequences of a war fought with nuclear weapons ${ }^{29}$ and a further report on the selection of casualties for treatment after a nuclear attack. ${ }^{30}$ Such reports clearly indicate that nuclear weapons are unusable, and they have been termed "instruments of genocide" rather than weapons. As medicine has so little to offer in the aftermath of nuclear war prevention is of paramount importance. At the Helsinki congress of the International Physicians for the Prevention of Nuclear War (IPPNW) in 1984 a medical prescription was put forward, in which a ban on all nuclear explosions was proposed as an essential step in restraining the nuclear arms race. The association, which currently represents 200000 doctors in 60 countries, is conducting a worldwide campaign for a comprehensive test ban treaty (Cease Fire ' 88 ). ${ }^{3}$

The resolution adopted by the World Health Assembly in 1983 included the statement that "nuclear weapons constitute the greatest immediate threat to the health and welfare of mankind." The current activity around the world by doctors and other health professionals drawing attention to the futility of medical planning for nuclear war, the diversion of resources needed for health care to military expenditure, and, above all, the emphasis on the critical importance of a comprehensive test ban, has its roots in the successful campaign waged by doctors and scientists against atmospheric testing. Prospects for a comprehensive test ban treaty currently look more hopeful than for some time; helping to bring it about would be a uniquely important exercise in primary prevention.

The United Kingdom affiliates of the Internationa Physicians for the Prevention of Nuclear War are the Medical Campaign Against Nuclear Weapons, Tress House, 3 Stamford Street, London SE1 9NT, and the Medical Association for the Prevention of War, 16b Prince Arthur Road, London NW3 6AY. The American affiliate is Physicians for Social Responsibility.

We thank the Physicians for Social Responsibility, International Physicians for the Prevention of Nuclear War, the Medical Campaign Against Nuclear Weapons, and the Medical Association for the Prevention of War for some of the material on which this article was based. We also thank Mrs Sheila Forman, Mrs Eva Goldenberg, Dr Patricia Lewis, and Professor Joseph Rotblat.

1 International Physicians for the Prevention of Nuclear War. Cease fire 88 IPPNW worldwide test ban campaign. Cambridge, Massachusetts: IPPNW, 1988. Available from IPPNW', 126 Rogers Street, Cambridge, Massachusetts 02142 .

2 Nishiwaki Y. The effects of the explosion of a hydrogen bomb. In: Medical Association for the Prevention of War Bulletin No 15. London: MAPW, 1955:2-70.

3 United Nations Scientific Committee on the Effects of Atomic Radiation. 1977 Report. Sources and effects of ionizing radiation. New York: United Nations, Report.

4 Dunham CL. Fallout from nuclear weapons tests. Biol Med Phys 1958;6: 175-99.

5 British Atomic Scientists' Association. Strontium hazards. Bulletin of the Atomic Scientists 1957; XIII:202-3.

6 United Nations Scientific Committee on the Effects of Atomic Radiation. 1982 Report. Ionizing radiation; sources and biological effects. New York: United Nations, 1982

7 Darby SC, Kendall GM, Fell TP, et al. A summary of mortality and incidence of cancer in men from the United Kingdom who participated in the United Kingdom's atmospheric nuclear weapons tests and experimental programmes. Br Med f 1988;296:332-8.

8 Seaborg G, Loeb BS. Kennedy, Krushchev and the test han. Berkelev: University of California Press, 1981.

9 Warren S. You, your patients and radioactive fallout. $N$ Engl f Med 1962;266: $1123-5$.

10 Kuroda PK, Nix J. Strontium 90 from the 1961 Soviet nuclear detonations. Science 1962;137:991-2.

11 Collins WR, Welford GA, Morse RS. Fallout from the 1957 and 1958 nuclear test series. Science 1961;134:980-4.

12 Eisenbud M, Mochizuki Y, Goldin AS, Laurer GR. Iodine-131 dose from Soviet nuclear tests. Science 1962;136:370-4
13 Yeabslev HJ, Gregory LP. Fallout in New Zealand: the results to June 1961. NZ Med f 1962;61:247-58.

14 Medical Research Council. Radioactive fall-out and the testing of nuclear weapons. Nature 1962;192:400-3

14a Rosenthal HL, Bird JT, Gilster JE, Pinto PVC, O'Neill S. Strontium-90 content of deciduous teeth of children. 7 Dent Res 1966;45:343-9.

15 Parker TJ. The alleged hazards from atomic fallout. I SC Med Assoc $1961 ; 57: 28-30$

16 Ervin FR, Glazier JB, Aronow S, et al. Human and ecologic effects in Massachusetts of an assumed thermonuclear attack on the United States. N Engl F Med 1962;266:1127-37

17 Sidel V, Geiger. J, Lown B. The physician's role in the postattack period. N Engl 7 Med 1962;266:1137-45.

18 Leiderman $\mathrm{PH}$, Mendelson JH. Some psychiatric considerations in planning for defense shelters. N Engl I Med 1962;266:1149-55.

19 Aronow S. A glossary of radiation terminology. N Engl J Med 1962;266: $1145-9$

20 Goldblat J. Arms control agreements. A handbook. London: Taylor and Francis, 1983.

21 Goldanskii V. A nuclear test ban: a Soviet scientist's perspective. IPPNW Report 1988;6:7-10. Available from IPPNW, 126 Rogers Street, Cambridge, Massachusetts 02142 .

22 Kidder RF. Maintaining the US stockpile of nuclear weapons during a low threshold or comprehensive test han. Livermore, California: Lawrence Livermore National Laboratory, 1987. (Available from the National Technical Information Service, United States Department of Commerce, 5285 Port Royal Road, Springfield, Virginia 22161.

23 DeWitt HE, Marsh GE. Weapons design policy impedes a test ban. Bulletin of the Atomic Scientists 1985; $41: 10-3$.

4 Stott R. Even before the bomb drops. London: Medical Campaign Against Nuclear Weapons, 1988

25 Smith R. Is research to be privatised? Br Med f 1988;296:185-8.

26 Middleton J, Routley J, Asquith P. What are health authorities doing about health problems caused by unemployment? Br Med f 1987:294:1551.

27 Sivard RL. W'orld military and social expenditures 1987-88. Washington, DC: World Priorities Inc, 1987.

28 British Medical Association. The medical effects of nuclear war. Chichester: Wiley, 1983.

29 British Medical Association. The long term environmental and medical effects of nuclear war. London: BMA, 1986.

30 British Medical Association. Nuclear attack ethics and casualty selection. London: BMA, 1988.

31 Delamothe T. After the summit. Br Med 7 1988;296:1728-9

\section{ANY QUESTIONS}

What might be the cause of recurrent superficial thrombophlebitis of both legs? What treatment is advised?

Recurrent episodes of phlebitis may be truly "idiopathic" but it is quite likely that a systemic.cause will come to light in due course. Occult malignancy of the bronchus or pancreas must remain a possibility. Buerger's disease can present in this way and the patient should be exhorted to stop smoking. There is quite a long list of disorders of coagulation and fibrinolysis that could present with recurrent phlebitis-for example, polycythaemia rubra vera, deficiencies of antithrombin III, protein $\mathrm{C}$ or protein $\mathrm{S}$, disorders of fibrinolysis, and Behçet's syndrome. The patient should be thoroughly screened by haematologists experienced in thrombotic problems. Depending on what is found it may be that the patient should be treated with long term oral anticoagulants, especially if there is evidence of deep vein thrombosis, which commonly coexists with superficial phlebitis. If a patient has ankle swelling that would suggest this possibility. Investigations should therefore include a phlebogram, which if positive would be a strong pointer towards prolonged anticoagulant treatment. Knee length graduated compression stockings might reduce the tendency for recurrence and lessen postphlebitic symptoms. - C V RUCKLEY, consultant surgeon, Edinburgh.

\section{Correction}

\section{Infection control revisited: dilemma facing today's} bronchoscopists

An authors' error occurred in this article by Dr P J V Hanson and others (16 July, p 185). "Prevalence" was substituted for "incidence" in the last sentence, which should read, "The plea that 'HIV is not a problem in our area' is not an argument against change, with an estimated 1:1000 people in the United Kingdom now infected with HIV, an incidence that is doubling every 10 months." 